Jack Fruit (Artocarpus integrifolia), and Avocado (Persea gratissima), for both food and income generation which also has helped a lot.

\section{Other Public Involvement}

Public meetings of local councils, churches' involvement, and holding of Nature talks in public places, have started bearing fruit, as has the obligation that anyone who cuts a tree must plant two others. Moreover, villagers are now forced to apply for government licences to cut down trees.

Recent developments in farming systems' research, especially regarding agro-ecosystems, have led to some invaluable regeneration of the environment: e.g. agricultural people have started rearing fish to help in the utilization of natural resources in rural areas, while poultryfarming and piggeries are on the increase to substitute for charcoal-burning activities — as does the 'send-a-cow' project by Anglican church-goers for the alleviation of poverty. A major public concern now is to educate and sensitize the community in local languages.

\section{Problems Still To Be Solved}

Extension of the Owen Falls Dam to increase power generation is being undertaken by the British Government and others. Whereas electricity has been an exclusive luxury of the relatively wealthy, and this has led the majority to use charcoal which is cheaper and still sufficiently abundant for domestic use, the Government is confident that if power can be made available in plenty for rural electrification, the rate of wood fuel (especially charcoal) consumption will fall dramatically.

Although alleviations of the above problems are being put into action, there are still other big ones that are not such as Water-hyacinth (Eichhornia crassipes) covering freshwater lakes and reservoirs, inadequate garbage-disposal in Kampala City, and the ignorance of indiscriminate use of chemicals in agriculture and elsewhere. But the Government is saying that the 21 st Century is projected to be the Environmental Century, and so we all need to work to have it be.

EDWARD E.S. MuKaSA clo POB 9932

Kampala, Uganda.

\title{
The Uganda Biosphere Club
}

$\mathrm{T}$ The Uganda Biosphere Club is an action organization that is dedicated to conserving the environment in general and, in particular, safeguarding The Biosphere as the sole habitat and life-support of all Humankind and Nature. Although Uganda is not a very large country, it constitutes an integral and in some ways unique part of The Biosphere, which is the only known source of life in the entire universe and hence our bounden duty to preserve at all costs.

The Club shall continue as established to be a nonpolitical and non-profit-making action-oriented concern cooperating and collaborating with any other appropriate bodies-corporate, concerns, or individuals, in the fulfilment of its objectives.

\section{AIMS AND OBJECTIVES}

1. To sensitize the public about the need for environmental protection and to provide the knowledge therefor by means of public and private lectures, seminars, and conferences, as well as by producing, publishing, and disseminating, tracts, pamphlets, books, periodicals, and films, and sponsoring, producing, directing, and presenting, cinema, radio, and/or television programmes, and by all other possible means, thereby:

a) Creating awareness of local or wider environmental hazards and ways of avoiding them, such as discouraging the use of environmentally dangerous chemicals which in many cases have been abolished in other countries but are still liable to be used in Uganda.

b) Promoting ecologically sustainable development through appropriate agricultural practices such as organic farming and agroforestry, and sustainable exploitation of forest and other environmental resources.

c) Promoting (where existing) or developing (where not existing) waste-recycling techniques and improved disposal of wastes to ease the problems of wastecreated pollution and general wastefulness of all kinds.

d) Promoting energy-saving techniques and alternative 'fuel' sources substituting for wood fuel. e) Promoting good soil management and conservation skills.

f) Protecting water-catchment areas, wetlands, and forests, and participating in tree-planting and reforestation programmes.

g) Promoting improved sanitary arrangements and health and other standards as a whole through realization of a better-to-live-in environment.

h) Practising all possible economy in the use especially of irreplaceable raw materials and of finite assets such as space on land.

2. To entertain any arrangement with the Ugandan Government and/or Environment Ministry and the National Environment Management Authority, and to obtain from any such Government or Authority any rights, privileges, and concessions, which the Club may consider desirable in the public interest to obtain, and to carry out, exercise, and comply with, any such arrangements, rights, privileges, and concessions, thereby:

a) Airing the Club's considered views concerning impending decisions and/or policies affecting the environment in any major way.

b) Endeavouring to find environmentally-acceptable ways of dealing with the Water-hyacinth and other foreseeable local problems.

c) Promoting research on environmental issues and conservation and uses of medicinal plants, etc.

3. To think and act holistically in deference to the tendency in Nature for the outcome to be different from the sum of the parts (or any local effects on a part), realizing that most people are interested only in their own particular environment without thinking of The Biosphere of which they constitute an integral part and without conceding that what they do may have a profound effect, collectively, on The Biosphere, its effective survival, and with it the conditions of life of any future generations of humans and other biota.

4. Generally to perform all such acts, and to promote all such activities, as are incidental or conducive to the achievement of any - and ultimately all — of the objectives of the Club. 
Executive Committee of the Uganda Biosphere Club

Chairman: Mr Edward E.S. Musaka

Vice-Chairman: Mr Paul Okitoy

Secretary-General: Mr David Nkwanga

Secretary: Miss Ruth Abwot

Treasurer: Mr John Mwesigwa
Member: Miss Margaret Nambi

Member: Mr Mathias Serugo

David Nkwanga, Secretary-General

The Uganda Biosphere Club

P.O. Box 9932

Kampala, Uganda.

\section{Soaring Temperatures in Ghana?}

$S^{t}$ tephens (1995) recently reported that temperatures in Ghana were increasing during this century and that the temperature rise could be evidence of a global warming signal. Using data from 11 stations, Stephens shows that the temperatures in the 1961 to 1990 period were higher than temperatures in the 1930 to 1960 period, noting that, between 1945 and 1990, temperatures in Ghana were "soaring' upwards; suggested causes included the 'greenhouse' effect and the potential influences of urbanization. While I commend Stephens for the effort, I conducted the following research that may be of interest to individuals concerned with regional climate changes over the period of reliable historical records.

I collected the 1945 to 1994 monthly temperature anomaly data from the widely-used Jones (1994) data-set for the $5^{\circ}$ latitude by $5^{\circ}$ longitude grid cell that contains most of Ghana (centred on $7.5^{\circ} \mathrm{N}, 2.5^{\circ} \mathrm{W}$ ). A plot of the 12 months' smoothed anomalies (Fig. 1) shows variability from year to year, but absolutely no evidence of any 'quite significant soaring of temperatures'. From 1945 to 1994 , the temperatures in this grid cell actually cooled slightly, but at a statistically insignificant rate. From 1945 to 1990 , there is simply no warming in the record.

The satellite-based lower-tropospheric temperature data developed and described by Spencer \& Christy (1990) provides another opportunity for testing temperature trends in Ghana. I collected the updated satellite data for the five $2.5^{\circ}$ latitude by $2.5^{\circ}$ longitude grid cells that cover Ghana for the period 1979 to 1994 , then smoothed the data using a 12-months filter, and plotted the data in Fig. 1. The satellite-based lower-tropospheric temperature data reveal a statistically highly significant cooling of $0.027^{\circ} \mathrm{C}$ per year over the period of record.

Although Ghana represents only $0.05 \%$ of the Earth's surface, it is important to analyse temperature trends even at this spatial scale. Stephens has shown that the temperatures at 11 stations in Ghana have increased since the end of World War II. However, this warming signal does not appear in the widely-used Jones (1994) data and it is certainly not found in the updated satellite-based Spencer \& Christy (1990) lower-tropospheric temperature data.

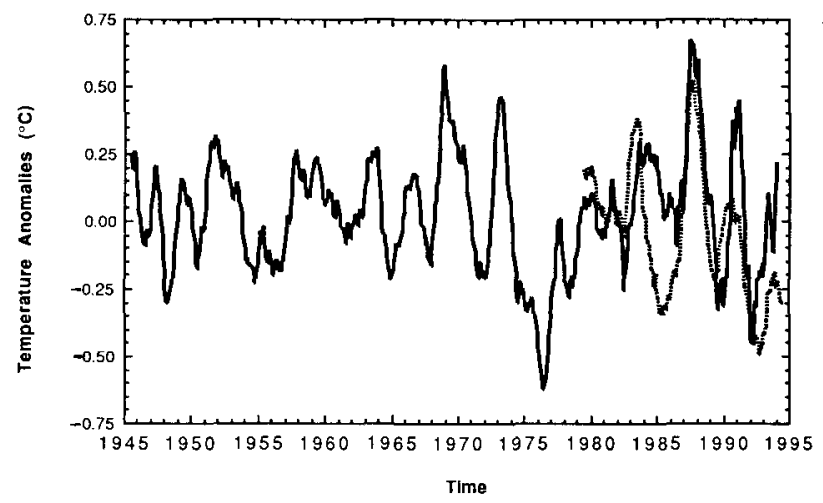

FIG. 1. Ghana monthly temperature anomalies based on the Jones (1994) near-surface air temperatures (solid line) and updated Spencer \& Christy (1990) satellite-based lower-tropospheric temperature measurements (dotted line).

While there may be any number of causes for the patterns reported by Stephens, it seems likely that the reported temperature rise in Ghana is more related to local urbanization effects than to any regional signal associated with the buildup of 'greenhouse' gases.

\section{REFERENCES}

JONES, P.D. (1994). Hemispheric surface air temperature variations: A reanalysis and an update to 1993. Journal of Climate, 7, pp. 1794-1802, illustr.

SPENCER, R.W. \& ChRISTY, J.R. (1990). Precise monitoring of global temperature trends from satellites. Science, 247, pp. 1558-62, illustr.

STEPHENS, C.E. (1995). Some indications of global warming in Ghana. Environmental Conservation, 22(2), pp. 174-5 \& 166, illustr.

Robert C. BAlling, Jr, Director

Office of Climatology

Department of Geography

Arizona State University

Tempe

Arizona 85287, USA.

\section{UN Recommendations on Transport of Dangerous Goods}

$\mathrm{D}$ uring the past 40 years, the 'Orange Book' has been a 'must' for all public authorities, carriers, and consigners handling substances which are hazardous for people and/or the environment. This 'United Nations Recommendations on the Transport of Dangerous Goods ${ }^{*}$ has become the generally acknowledged source of technical provisions, which are now implemented world-wide. Many Governments in all inhabited continents have based their national legislation on these recommendations, and their implementation is also guaranteed through international conventions regulating all modes of transport - whether by road, rail, inland waterways, air, or maritime shipping.

*Recommendations on the Transport of Dangerous Goods, Ninth revised edition. United Nations, New York and Geneva, ISBN 92-1139084-6, ISSN 1014-5753, UN Sales Nr E.95.VIII.1, Price US \$95. Also available on diskette (Sales Nr 94.VIII.2, Price US \$250.)
All the dangerous substances and articles that are most commonly carried are listed in this 'Orange Book'. They are divided into nine classes: namely 1 Explosives; 2 Gases; 3 Flammable liquids; 4 Flammable solids; 5 Oxidizing substances and organic peroxides; 6 Toxic and infectious substances; 7 Radioactive material; 8 Corrosive substances; and 9 Miscellaneous dangerous substances and articles.

The 'Orange Book' contains provisions for packing dangerous goods, marking and labelling packages, placarding transport units, and shipping documentation. It also includes provisions for the construction of packagings, intermediate bulk containers, multimodal tank-containers, as well as for their testing and approval.

The ninth revised edition of the 'Orange Book' has recently been published in English but will, at a later stage, 